\title{
Leadership Intellectual Stimulation and Team Learning: the Mediating Role of Team Positive Affect ${ }^{*}$
}

\section{Estimulación intelectual del líder y aprendizaje del equipo: El rol mediador del afecto positivo del equipo}

Received: 31 May 2016 | Accepted: 03 May 2017

\author{
ISRAEL SÁNCHEZ-CARDONA ${ }^{\mathrm{a}}$ \\ Universidad Carlos Albizu, Puerto Rico \\ ORCID: http://orcid.org/0000-0001-8925-5023 \\ Marisa Salanova Soria \\ Universitat Jaume I, España \\ Susana Llorens-Gumbau \\ Universitat Jaume I, España
}

\begin{tabular}{lll}
\hline a Correspondance & author. & E-mail: \\
isanchez1@albizu.edu
\end{tabular}

How to cite: Sánchez-Cardona, I., Salanova, M., \& Llorens-Gumbau, S. (2018). Leadership intellectual stimulation and team learning: The mediating role of team positive affect. Universitas Psychologica, 17(1), 1-16. doi: https://doi.org/10.11144/Javeriana.upsy17 -1.list

\begin{abstract}
This study investigates how leadership intellectual stimulation relates to team positive affect and team learning. We explore the role of positive affect as mediator between leadership intellectual stimulation and team learning. Using a cross-sectional sample of 562 employees, nested within 130 teams from 44 small- and medium-size organizations, we implemented Structural Equation Model analysis at the team level. Results provide evidence of the strong relationship that intellectual stimulation has on team learning and team positive affect, as well as the potential of positive affect for stimulating team learning. Team positive affect serves as a partial mediator between intellectual stimulation and team learning, contributing to explain significant additional variance. Leadership intellectual stimulation is a relevant team social resource that provides support for team learning. Also, positive affect contributes significantly to improve learning among teams. This suggests the importance of developing leadership behaviors that encourage learning and team positive affect, which contributes to team learning and hence, performance.

Keywords

Leadership intellectual stimulation; Transformational leadership; Team positive affect; Team learning.
\end{abstract}

\section{RESUMEN}

Este estudio examina cómo la estimulación intelectual de los líderes se relaciona con el afecto positivo y el aprendizaje de los equipos. En específico, explorarnos el rol mediador del afecto positivo entre la relación de la estimulación intelectual de los líderes y al aprendizaje a nivel de los equipos. Realizamos análisis de modelos de ecuaciones estructurales a nivel grupal utilizando una muestra transversal de 562 empleados, anidados en 130 equipos de 40 pequeñas y medianas organizaciones. Los resultados proveen evidencia de la fuerte relación entre la estimulación intelectual y el afecto positivo, así como del potencial del afecto positivo para estimular el aprendizaje del equipo. El afecto positivo sirve como un 
mediador parcial contribuyendo a explicar varianza adicional significativa. La estimulación intelectual de los líderes es un recurso social relevante que provee apoyo al aprendizaje en los equipos. Del mismo modo, el afecto positivo contribuye significativamente a mejorar el aprendizaje. Esto sugiere la importancia de desarrollar comportamientos de los líderes que fomenten el aprendizaje y el afecto positivo, los cuales contribuyen al aprendizaje y al desempeño a nivel grupal.

Palabras clave

estimulación intelectual; liderazgo transformacional; afecto positivo; aprendizaje de equipos.

Nowadays, organizations strive to cultivate positive psychological states and behaviors within its workforce for adaptability and resiliency in turbulent times (Salanova, Llorens, Cifre, \& Martínez, 2012). Salanova et al. (2012) proposed a heuristic model to explain Healthy and Resilient Organization (HERO), which are those that proactively and continuously develop organizational practices and resources to promote healthy outcomes in individuals and teams that, in turn, lead to team and organizational effectiveness. From this perspective, leaders, as social resources, play an important role in organizations to shape team and organizational processes to improve effectiveness and well-being (Cruz-Ortiz, Salanova, \& Martinez, 2013a, 2013b; Hannah \& Lester, 2009). Transformational leaders are those who can inspire their followers, increment their maturity and motivation to go beyond their personal interest, having a direct impact on their colleagues' well-being and effectiveness (Cruz-Ortiz et al., 2013a). Leaders provide vision, inspirational communications, help their followers to see diverse perspectives, and provide support and recognition (Bass, 1985; Rafferty \& Griffin, 2004). On the contrary, transactional leaders focused mainly in followers meeting the expectations (Judge \& Piccolo, 2004). The developmental and person-focused approach of transformational leadership behaviors are crucial for the optimization of team members' potentialities.

From the transformational leadership approach, intellectual stimulation is perhaps the most commonly understudied dimension (Rafferty \& Griffin, 2004); nonetheless it may have a powerful impact on team process, such as team learning. Through intellectual stimulation leaders continuously encourage team members to think and perform in new ways by challenging their own beliefs and supporting new and innovative ways of actions. Moreover, it is well known that leaders infuse positive psychological and affective states that help teams to increase both performance and well-being (Pirola-Merlo, Härtel, Mann, \& Hirst, 2002; Salanova et al., 2012). Leadership research points that certain leadership behaviors have an effect over employees' optimism and enthusiasm (Bono, Foldes, Vinson, \& Muros, 2007), affective commitment (Rafferty \& Griffin, 2004), and it can help to create a positive team climate (Hernández-Baeza, Araya Lao, García Meneses, \& González Romá, 2009). The Broaden and Build theory posit that positive affectivity (i.e., emotions) broadens peoples' modes of thinking and action, and builds enduring resources (i.e., cognitive, social) (Fredrickson, 2001; Sekerka \& Fredrikson, 2008). Additionally, team positive affect has a significant influence on team dynamics, behaviors, and performance (Collins, Lawrence, Troth, \& Jordan, 2013). As suggested by Rafferty and Griffin (2004), intellectual stimulation may have an effect on the affective responses of team members (e.g., affective commitment) through the perception that leaders value their contribution and are concerned with the team development. Thus, intellectual stimulation may stimulate team learning by infusing positive affect, which can contribute members to engage in collective learning.

The aim of this study was to examine how intellectual stimulation of leaders relates to team positive affect and team learning. Concretely, we explore the role of positive affect as a mediator between leadership intellectual stimulation and team learning. We based our propositions on the Healthy \& Resilient Organization Model (Salanova et al., 2012), which proposes that teams and organizations can develop their effectiveness and resilience 
through three interrelated blocks of variables: healthy organizational resources and practices, healthy employees, and healthy organizational outcomes. The model highlights the importance of social resources, such as leadership behaviors, which are relevant to increase the connections employees have with the people they work with. Moreover, this model postulates the relationship of these interpersonal resources to promote both cognitive and affective psychological resources, which are crucial to develop healthy employees and outcomes. Based on this idea, we argue that team learning is one way to promote continuous improvement and performance in shifting times (Edmondson, 1999; Van Der Vegt \& Bunderson, 2005) and that team leaders play a key role stimulating followers intellectually through team positive affect (Rafferty \& Griffin, 2004).

Although previous evidence supports the role of leaders for team learning (Edmondson, 1999; Hetland, Skogstad, Hetland, \& Mikkelsen, 2011), this study contributes to examine the role of a set of leader behaviors related to learning activities (i.e., intellectual stimulation) at the team level (Morgeson, DeRue, \& Karaman, 2010; Salanova et al., 2012). Our aim is to contribute to the scarce literature on the contribution of team positive affect on team learning process. This topic has not been deeply addressed in empirical research, although theoretical propositions suggest that positive affect, and in specific emotions, can expand peoples' mode of thinking and enlarge their possibilities for action (Frederickson, 2001, 2003; Vacharkulksemsuk \& Fredrickson, 2013).

\section{Leadership and team learning}

The role of leadership in facilitating learning efforts is fundamental within organizations. Leaders play a central role in encouraging learning and offer the required guidance for organizations to integrate and sustain learning processes (Carmeli, \& Sheaffer, 2008; Edmondson, 2003; Song, Kolb, Lee, \& Kim, 2012). More specific, leadership behaviors aimed to encourage learning (i.e., intellectual stimulation) serve as a resource to promote a learning environment characterized by reflection, challenging ideas, and new ways of thinking and action (Edmondson, 1999, 2002, 2003). Team learning is a process through which team members seek to acquire, share, refine, or combine relevant knowledge interacting with one another, as well as to reflect upon feedback and make changes to adapt and improve (Edmondson, 1999).

Leaders promotes team learning through diverse sets of behaviors such as questioning, providing information and exchanging solutions, stimulating curiosity, encouraging voice, promoting a culture for learning, helping to interpret situations in new ways, modeling new ways of thinking and action, providing coaching, being open to change, and developing mechanisms for learning transfer (Carmeli \& Scheaffer, 2008; Edmondson, 1999, 2003; Sarin $\& \mathrm{McDermott}, 2003)$. From a unified leadership approach, transformational leadership approach is perhaps the closest to team and organizational learning (Song et al., 2012).

Transformational leaders act as a social resource that inspires and motivates followers through the transformation of their attitudes, beliefs, and values, leading to performance and well-being improvements (Bass, 1985; Nielsen \& Munir, 2009; Rafferty \& Griffin, 2004). Transformational leadership is conceptualized as a multidimensional construct. Bass' (1985) Transformational Leadership Theory identified the following dimensions: Charisma or Idealized influence; Inspirational motivation; Intellectual stimulation; and Individualized consideration. Raferty and Griffin (2004) re-examine the theoretical model presented by Bass (1985) and suggested five sub dimensions of transformational leadership: (1) Vision, which refers to the expression of an idealized picture of the future based around value; (2); Inspirational communication, which refers to the expression of positive and encouraging messages about the organization and statements that build motivation and confidence; (3); Supportive leadership, which refers to leaders expressions of concern for followers and considering their 
individual needs; (4) Intellectual stimulation, through which leaders' enhance employees' interest in, and awareness of problems, and increasing their ability to think about problems in new ways; and (5) Personal recognition, which refers to the provision of recognition and acknowledgement for goal achievement.

Even though extensive research has been conducted linking this person-focused leadership behaviors to team effectiveness, productivity, and positive affective states (Bono et al., 2007; Burke et al., 2006), few empirical studies have addressed the relationship between transformational leadership and team learning. Even more, most of the research on transformational leadership is conducted using a unique factor of transformational leadership. Nonetheless, as suggested by previous research, the study of particular leadership behaviors instead of focusing on multidimensional aspects of leadership is still needed (Burke et al., 2006; Nielsen \& Munir, 2009). The study of one particular dimension of leadership allows for the development of specific organizational interventions to promote leaders' behaviors that improve specific employee and team wellbeing states, development of capabilities, and therefore, organizational outcomes (Nielsen \& Munir, 2009).

Nielsen and Munir (2009), for example, suggested that "through intellectual stimulation leaders encourage followers to make their own decisions and be creative and innovative in their work, and as such they may feel more challenged and thereby also more aroused" (p. 315). According to Rafferty and Griffin (2004) intellectual stimulation is perhaps the most underdeveloped component of transformational leadership; nonetheless, it encompasses a more focused and internally consistent set of behaviors. Intellectual stimulation provide a social resource through which team members are challenged and encouraged to think creatively, experiment, participate, and solve problems in their daily work (Rafferty \& Griffin, 2004; Zhou, Hirst, \& Shipton, 2012).

When leaders stimulate employees intellectually, team members are able to increase their awareness to problems, which allows them new ways of looking at old problems (Rafferty \& Griffin, 2004). This suggests a meaningful relationship between leadership behaviors and perceptions of a learning-supporting context (Hetland et al., 2011). Through intellectual stimulation leaders can create an environment for questioning assumptions, differing perspectives, encouraging new ways of thinking, and suggesting new ways of seeing problems.

At the team level, Morgeson et al. (2010) suggest that one important function of leaders concerns challenging the team, which involves "challenging teams with regard to their task performance and confronting the team assumptions, methods, and processes in an effort to find the best ways of accomplishing the team's work" (p. 21-22). This leadership function is reflected in the intellectual stimulation sub-dimension of transformational leadership; however, traditionally this sub-dimension has been focused at the individual level, representing a limitation for the team level of analysis. In our study, we overcome this limitation rewording and adapting intellectual stimulation measure to focus at the team level using a referent shift consensus composition (Chan, 1998).

\section{Leaders and team positive affect}

Leaders have an important influence over the affective well-being of their followers (Bono et al., 2007; Kelly \& Barsade, 2001). Traditional influential theories of leadership, such as transformational leadership, include an emotional component. Leaders help to create shared emotional experiences that bond group members together and infuse performance. For example, Hernández-Baeza et al. (2009) found that leadership charisma has a significant influence in fostering positive team climate and preventing negative affective climate.

In our study, we center the attention on intellectual stimulation as a leader behavior that potentially influences learning activities and processes in teams. When 
leaders encourage learning behaviors through intellectual stimulation, they can foster emotional contexts as well, which help to better functioning and persevering under adverse circumstances (e.g., Fredrickson, 2003). Rafferty $\&$ Griffin (2004) found an unexpected relation between intellectual stimulation of leaders and affective commitment. They suggest that even though intellectual stimulation may provide employees with more role ambiguity and conflict, it is also a way through which leaders express value to team member's contribution. This sense of value may elicit affective states in employees encouraging them to actively engage in group processes and outcomes (Kelly \& Barsade, 2001).

\section{Team positive affect and team learning}

Research shows that positive affect precedes desirable individual and team outcomes (Kelly \& Barsade, 2001). Team affect, as a shared pattern of affective states of group members (Kelly \& Barsade, 2001), has gained considerable attention since it promotes and derives valuable team dynamics and outcomes such as: coordination, cooperation, performance (Salanova, Llorens, \& Schaufeli, 2011), and organizational learning (Scherer \& Tran, 2001; Vince, 2002).

In the workplace, positive affect may elicit better relationships among team members, as well as broaden attention to environmental context, thoughts, and actions, encouraging novel ideas and deeds (Fredrickson, 2001; Vacharkulksemsuk \& Fredrickson, 2013). Thus, emotional climate influences team and organization dynamics such as idea-generation, creativity, adaptability to change, and facilitation or inhibition of learning processes (Scherer \& Tran, 2001). This expands the perspective in the study of team learning, which essentially focuses on aspects such as efficacy beliefs, trust, and psychological safety (Edmonson, 1999; Edmondson, Dillon, \& Roloff, 2007; Van der Vegt \& Bunderson, 2005; Van den Bossche, Gijselaers, Segers, \& Kirschner, 2006).

| Universitas Psychologica | V. i7 | No. I | 2018 |
Collective positive affect can transform organizations making its members more flexible, empathetic, and creative, contributing to organizational effectiveness and adaptation (Fredrickson, 2003). Theoretically, the Broadenand-Build Theory (Frederickson, 2001) explains how positivity relates to well-being and the development of resources which help for adaptability and performance. Additionally, positive emotions broaden awareness as well as thinking and action repertoires. On the other hand, positive emotions contribute to build enduring cognitive, physical, social, and relational resources (Salanova et al., 2011; Vacharkulsemsuk \& Fredrickson, 2013). In this sense, positive affective states enlarge capacities to generate new ideas, increase their alternatives for action, improve member connectivity, and contribute to the overall well-being (Sekerka \& Fredrickson, 2008; Vacharkulsemsuk \& Fredrickson, 2013).

Previous research evidences the relationship of affective states (positive and negative) on several work outcomes. For example, Tsai, Chen, and Cheng (2009) found that leadership indirectly influences performance and helping behaviors through positive moods. These results contribute to the scarce literature regarding the mediating role of positive affective states between leadership and performance outcomes. Positive affect has a great potential to foster strong social resources at work, but still more understanding is needed on what outcomes positive affect yields at the team level (Vacharkulsemsuk \& Fredrickson, 2013).

The current study aims to explore the role of intellectual stimulation and positive affect on team learning, giving particular attention to the role of positive affect between intellectual stimulation of the leader and team learning. Leaders can promote team learning through intellectual stimulation and these intellectual challenging behaviors instill a positive affective context within teams. When intellectually stimulated, team members may feel that leaders are concerned with their growth and development, as well as interested in their contributions to the team, infusing 
positive affect among team members (Rafferty $\&$ Griffin, 2004). This collective positive affect may broaden thinking and build cognitive, social, and relational resources, especially stronger ties among team members, fostering sharing of ideas, reflecting and questioning assumptions (Vacharkulksemsuk \& Fredrickson, 2013). In this sense, leaders intellectually stimulate or challenge their teams to contribute to their learning process. These leadership behaviors may also relate significantly to team positive affect, which also contributes to explain why teams engage in team learning.

This study will contribute to the current literature examining how leaders and positive affect at the team level promotes learning. Moreover, this exploration will provide evidence of the role of positive affect on the relationship between leadership intellectual stimulation and team learning, going a step further from the study of mediating variables centered only on interpersonal or cognitive states (e.g., efficacy, psychological safety, collaboration) (Edmondson, 1999; Edmondson et al., 2007; Van der Vegt \& Bunderson, 2005; Van den Bossche et al., 2006). We propose the following hypotheses:

$\mathrm{H}_{1}$ : Leadership intellectual stimulation will be positively related to team learning and team positive affect.

$\mathrm{H}_{2}$ : Team positive affect will mediate the relationship between leadership intellectual stimulation and team learning.

\section{Method}

\section{Data collection}

A sample of 562 employees nested within 130 work units from 44 Spanish Small and Medium Size Enterprises (SME) was used in the study. Fifty-two percent (52\%) of the participants were men, and $84 \%$ had a permanent contract. The average job tenure was 5.89 years $(S D=6.08)$. Eighty percent $(80 \%)$ of the organizations were from the service sector, $19 \%$ from industry, and $1 \%$ from the construction sector. Finally, teams had an average of nearly six members (Median $=$ 5) with a range from 2 to 18 members.

Organizations were selected by convenience and invited (personally or by phone) to participate voluntarily in this research. Once agreed to participate, the questionnaires (30 minutes to administer) were distributed to employees and collected at the company by the researchers. Employees completed the questionnaire with their work-unit as their main referent, as stipulated in the HERO Model (Salanova et al., 2012). Only employees with a tenure in the company of at least six months participated in the study to ensure they had time to settle into their job and the organization. Confidentiality of the answers was guaranteed.

\section{Measures}

Leadership intellectual stimulation was assessed by three items of the intellectual stimulation subdimension of the transformational leadership scale (Rafferty \& Griffin, 2004) validated for aggregated data at the team level by Salanova et al. (2012). Respondents answered using a 7 point Likert type scale ranging from 0 (totally disagree) to 6 (totally agree). The items were: "Our supervisor... has ideas that have forced us to rethink some things that we have never questioned before; ...challenges us to think about old problems in new ways; ... has challenged us to rethink some of our basic assumptions about our work" ( $\alpha=0.83)$.

Team positive affect was assessed by six items validated for aggregated data at the team level by Salanova et al. (2012). Respondents answered using a 7-point face rating scale which allows capturing the emotional dimension of the construct examined. The items were as follow: "In the last year, my group has felt: relaxed, enthusiastic, optimistic, comfortable, resilient, satisfied" $(\alpha=0.89)$.

Team learning was assessed by three items based on previous definitions and scales of team leaning (Edmondson, 1999; Van der Vegt \& Bunderson, 2005). Respondents answered using a 7-point Likert type scale ranging from 0 (totally disagree) 
to 6 (totally agree). The items were: "In my team, we share information about how to do our work," "In my team, we criticize each other's work in order to improve performance," and "My team is open to exchange innovative and creative ideas" $(\alpha=0.74)$.

\section{Data Analysis}

Since data were self-reported results, it might be influenced by common method variance. Thus, we conducted a one-factor test confirmatory factor analysis to assure validity of the measures (Podsakoff, MacKenzie, Lee, \& Podsakoff, 2003) using individual responses data set $(N=562)$. Next, as all variables were measures at the team level, different indices of agreement of employee perceptions in teams were calculated. First, to examine consistency and agreement, we used a consistency-based approach computing Intraclass Correlation Coefficients ( $\mathrm{ICC}_{1}$ and $\left.\mathrm{ICC}_{2}\right): \mathrm{ICC}_{1}$ is interpreted as the proportion of the total variance that can be explained by the group membership, and the $\mathrm{ICC}_{2}$ is an estimate of the reliability of the group means (Bliese, 2000; James, 1982). Values greater than 0.12 and 0.6 , for the $\mathrm{ICC}_{1}$ and $\mathrm{ICC}_{2}$ respectively, indicate an adequate level of withinunit agreement and support aggregation. In addition, we assessed within-team agreement in each measure computing the $r_{w g(j)}$ for multi-item scales (James, Lawrence, Demaree, \& Wolf, 1993) as recommended by LeBreton and Senter (2008). Interrater agreement to justify aggregation of the study variables was concluded when $r_{w g(j)}$ was around 0.51 or greater, which means moderate to very strong agreement according to the revised standards for interpreting interrater agreement estimates (Biemann, Cole, \& Voelpel, 2012; Lebreton $\&$ Senter, 2008). Finally, one-way analyses of variance were computed in order to ascertain whether there was significant between-group discrimination for the measures.

Following aggregation, we computed descriptive statistics, internal consistencies (Cronbach $\alpha$ ) and correlations between variables at the individual $(n=562)$, and the team $(n$ $=130$ ) levels using SPSS 21.0. We tested the hypothesized model using structural equation modeling (SEM) with AMOS 21 maximum likelihood estimation method with aggregated data at the team level. We performed a mediation analysis and computed bootstrapped confidence interval for the indirect effect (Preacher \& Hayes, 2008).

The following fit indices were considered to evaluate model fit. Three absolute fit indices were calculated: Chi-square $\left(\chi^{2}\right)$ goodnessof-fit statistic, Root Mean Square Error of Approximation (RMSEA), and Standardized Root Mean Square Residual (SRMR) were evaluated. Values of RMSEA below 0.08 and 0.05 indicate a reasonable and good fit, respectively, and SRMR values lower than 0.08 are indicative of a good fit (Hu \& Bentler, 1999). The $\chi^{2}$ goodness-of-fit index is sensitive to sample size and the use of relative goodness-of fit indices is recommend (Bentler, 1990). Accordingly, three relative goodness-of-fit indices were examined: Incremental fit index (IFI), Normed Fit Index (NFI), Tucker-Lewis Index (TLI), in addition to the Comparative Fit Index (CFI). Values equal or greater than 0.95 indicate a good fit for the relative indices ( $\mathrm{Hu} \&$ Bentler, 1999). Finally, we computed the Akaike Information Criterion (AIC) to compare competing models; the lower the AIC index, the better the fit is.

\section{Results}

\section{Descriptive and Aggregation Analyses}

Table 1 shows means, standard deviations, internal consistencies (Cronbach $\alpha$ ), composite reliability and average variance extracted, correlations, and aggregation indices of all study variables. All correlations were statistically significant and in the expected direction. Considering that team size might be related to transformational leadership and/or team process (Cruz-Ortiz et al., 2013a; Kozlowski \& Ilgen, 2006), we examined the relationship of team size with variables aggregated at the team level. 
Team size was not statistically significant with intellectual stimulation $(r=-0.116, p=0.19)$, team positive affect $(r=-0.036, p=0.68)$, and team learning $(\underline{\mathrm{r}}=-0.093, p=0.293)$. Thus, to assure model parsimony and following recent suggestions in the use of control variables in organizational research (Becker et al., 2016), we did not incorporate team size into the model.

$\mathrm{ICC}_{1}$ (range 0.26 to 0.32 ), $\mathrm{ICC}_{2}$ (range 0.61 to 0.8 ) and the median of $r_{w g(j)}$ (range 0.75 to 0.79 ) exceeds the recommend criteria of $0.12\left(\mathrm{ICC}_{1}\right), 0.6\left(\mathrm{ICC}_{2}\right)$ and greater than $0.51\left(r_{w g(j)}\right)$. One-way analysis of variance indicated statistically significant between-group discrimination of intellectual stimulation, $F(129$, $432)=2.69, p<0.001$; team positive affect, $F(129,432)=3.09, p<0.001$; and, team learning, $F(129,432)=3.2, p<0.001$. Thus, results provide empirical support for data aggregation at the team level.

A one single-factor Confirmatory Factor Analysis (CFA) was computed using individual data set, for the variables in the study. The one single-factor model showed poor fit to the data in comparison with a 3 -factors model $\left(\chi^{2}\right.$ (51) $=106.14, \mathrm{RMSEA}=0.04, \mathrm{SRMR}=0.03, \mathrm{CFI}$ $=0.98$, NFI $=0.98$, TLI $=0.98$, IFI $=0.98$, $\left.\mathrm{AIC}=160.13, \Delta \chi^{2}(3)=876.48, p<0.001\right)$. Average Variance Extracted (AVE) ranges from 0.51 to 0.62 ; square of the correlations of any pair of variables (ranged from 0.44 to 0.55 ) were lower than the AVEs, showing evidence of discriminant validity of the three latent factors.

\section{Table 1}

Descriptive analysis and aggregation indices

\begin{tabular}{lcccccccccc}
\hline & $M$ & $S D$ & $C R$ & $A V E$ & $I C C_{(1)}$ & $I C C_{(2)}$ & $r_{w g(i)}$ & 1 & 2 & 3 \\
\hline Leadership & & & & & & & & \\
$\begin{array}{l}\text { Intellectual } \\
\text { Stimulation }\end{array}$ & 3.97 & 1.11 & 0.83 & 0.62 & 0.28 & 0.63 & 0.79 & $(0.83)$ & 0.48 & 0.64 \\
Team Positive & 4.02 & 1.16 & 0.9 & 0.59 & 0.33 & 0.68 & 0.75 & 0.37 & $(0.89)$ & 0.52 \\
Affect & 4.16 & 0.75 & 0.51 & 0.34 & 0.69 & 0.78 & 0.44 & 0.36 & $(0.74)$ \\
Team Learning & 4.60 & 1.16 & & & & & & & &
\end{tabular}

Note. Correlations are presented at the individuallevel ( $n=562$, below the diagonal) and at the team-level ( $n=130$, above the diagonal). All correlations are significant at $p<0.01$ Coefficient alpha reliability estimates for the individual database are listed in the diagonal in parentheses.

\section{Model Fit: Structural Equation Modeling}

We used the aggregated database at the team level to test the hypothesized model using SEM analysis. Table 2 reports the main results of the mediating analysis. Results indicate that the full mediation model ( 1 $_{\text {Full Mediation }}$ ) does not fit well to the data. Values of RMSEA were above recommended criteria.

We further examined a second model (M2 Partial Mediation) in which leadership intellectual stimulation relates to both team learning and team positive affect. This M2 presents satisfactory fit to the data in comparison to M1 $\left(\Delta \chi^{2}(1)=42.44, p<0.001\right)$. An inspection of the modification indices of the model revealed that if the error terms of enthusiasm and optimism were covariate, model fit improves significantly. This covariation was conceptually in accordance of positive affect literature, which suggests that optimism and enthusiasm are both part of the same axis of affective well-being characterized by high pleasure and arousal (Warr, 1990). This revised model (M3 Partial Mediation Revised) presents the best fit to the data in comparison with M2 $\left(\Delta \chi^{2}(1)=16.5, p<0.001\right)$.

All path coefficients in M3 Partial Mediation Revised are significant (see Figure 1. Intellectual stimulation is significantly related to team positive affect, $\beta=0.56, p<0.001\left(R^{2}=32 \%\right)$. When controlling for intellectual stimulation, team positive affect was significantly related to team learning, $\beta=0.27, p<0.001\left(R^{2}=17\right.$ $\%)$. The direct effect of leadership intellectual stimulation on team learning, controlling for team positive affect was also significant, $\beta=$ $0.61, p<0.001\left(R^{2}=38 \%\right)$. Results based on 500 bootstrapped samples' confidence interval indicated that team positive affect significantly and partially mediates the relationship between leadership intellectual stimulation and team learning, $\beta=0.15$, (95\% CI $[0.07,0.29])$.

Overall, these results support that team positive affect partially mediates the relationship between leadership intellectual stimulation and team learning. Intellectual stimulation has a 
positive and significant influence on team positive affect, which in turn is positively and significantly associated with team learning. Finally, intellectual stimulation also shows a positive significant direct relationship with team learning.

\section{Table 2}

Fit Indices for mediation SEM analysis $(n=130$ teams)

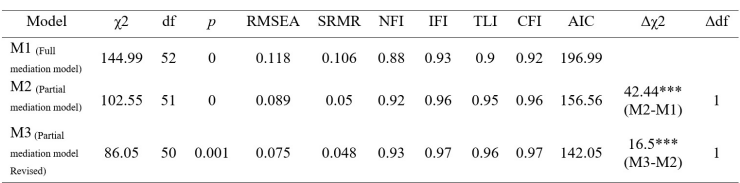

Note $\chi^{2}=$ Chi-square; $\mathrm{df}=$ degree of freedom; RMSEA $=$ Root Mean Square Error of Approximation; SRMR $=$ Standardized root mean square residual; NFI = Normed Fit Index; IFI = Incremental Fit Index; TLI = Tucker-Lewis Index; CFI = Comparative

Fit Index; AIC = Akaike Information Criterion; $\Delta=$ difference. ${ }^{* * *} p<0.001$.

Figure 1

Mediation model with standardized estimates $(n=$ 130 teams)

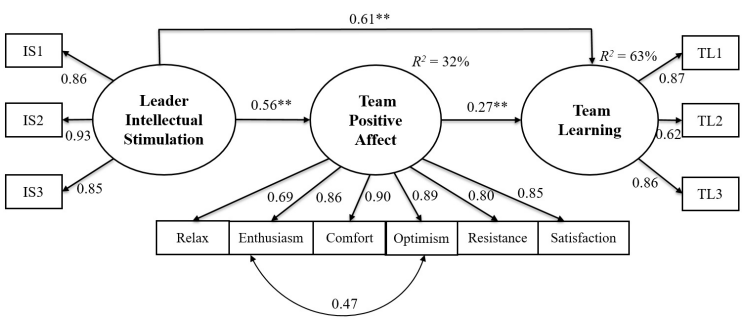

\section{Discussion}

The aim of this study was to examine how team positive affect mediates leadership intellectual stimulation and team learning. As we discussed, several authors suggest the importance of evaluating the influence of specific leadership behavior on team and organizational processes (e.g., Burke et al., 2006; Nielsen \& Munir, 2009). Since team learning becomes increasingly critical as organizational changes and complexity intensifies (Edmondson, 1999), specific leadership behavior that leverage team learning activities seems to be important to investigate. Moreover, adding to the existence evidence, this research examines the role of team positive affect in the relationship between leadership intellectual stimulation and team learning. In addition, it contributes to enhance the understanding of leadership behavior to promote healthy teams (Salanova et al., 2012). The results show that intellectual stimulation has a positive and significant relationship on team learning when tested at the collective level. This coincides with past research, which also suggests that leaders can promote a learning environment encouraging reflection and new ways of thinking and action (Edmondson, 1999, 2002, 2003). Leaders, as a social resource, can motivate and empower teams to improve their collective way to think and act.

Intellectual stimulation, as a leadership behavior, encompasses a series of leadership activities that are closely related to team learning, since these leadership actions are aimed to challenge and encourage team members to reflect, think, and act differently and in creative new ways. Thus, it is reasonable to understand why intellectual stimulation contributes significantly to the promotion of team learning. However, it is worth noting that leaders may have a direct influence in teams' positive affect, which contributes to team learning as well. Leader behaviors that encourage learning promote both team learning and an affective climate, which in turn, increments team learning. Results of the mediation analysis showed that team positive affect relates significantly with intellectual stimulation and team learning, and that positive affect partially mediates the relationship. This provides evidence for the potential of team positive affect for team learning considering the capacity of positive affective states to broaden thinking and action repertoires. These results provide intriguing avenues for future understanding of how positive affect may have an influence on team learning through the development of other social or personal resources.

Also, intellectual stimulation has a significant effect on team positive affect. These results contribute to the existing literature on the 
link between leadership and team positive affective states but considering one specific set of leader behaviors. Additionally, it contributes to generate new questions regarding the mediating role of team positive affect between intellectual stimulation of the leader and other variables such as innovative and creative behavior/ performance, helping behaviors (Tsai et al., 2009), or cooperation (Sekerka \& Fredrickson, 2008). As suggested by Sekerka and Fredrickson (2008) positive affective climate is a key resource to energize and sustain transformation; thus, by creating experiences that foster collective positive emotional climates, practitioners could stimulate cooperation in route to change. However, change does not come alone; it is inherently linked to learning new ways of thought and behavior (Edmondson, 2002). In this line, it might be possible that intellectual stimulation fosters collective positive affective environment, which in turns influences some team characteristics or process such as cohesion, coordination, or even psychological safety, which finally drives higher team learning. Future research should be conducted in this area.

Team positive affect also contributes to create a context in which team members can feel free to exchange ideas, knowledge, insights, reflect and criticize current assumptions, reflect upon feedback, and generate new ways of thinking and action. In accordance, team positive affect influences team and organizational dynamics such as idea-generation, creativity, adaptability to change, and facilitation or inhibition of learning processes (Scherer \& Tran, 2001). Positivity broadens the scope of attention and cognition and lead to a widened array of thought and actions. This result provides evidence of the potential of team positive affect to foster team learning, which in turn potentiates more effective groups.

Although the focus of the present study was on a specific leadership dimension, namely intellectual stimulation, it is possible that other transformational leadership behaviors also significantly relate to the current study outcomes of team positive affect and team learning. Bono et al. (2007) provide compelling evidence that leadership behaviors have an influence on employees' optimism and enthusiasm. Transformational leadership as a whole construct has been related to team affective states, satisfaction, and affective commitment (Chi, Chung, \& Tsai, 2011; Chi \& Huang, 2014; Stinglhamber, Marique, Caesens, Hanin, \& De Zanet, 2015; To, Tse, \& Ashkanasy, 2015), and positive affect has been suggested as a relevant boundary condition for the influence of transformational leadership on effectiveness and behaviors (Gilmore, $\mathrm{Hu}$, Wei, Tetrick, \& Zaccaro, 2012). HernandezBaeza et al. (2009), for example, found that transformational leadership (i.e., charisma) infuse positive affect in their followers. In a meta-analytical study conducted by Dumdum, Lowe, and Avolio (2002), they found that transformational leadership consistently related to job satisfaction and this relationship was stronger than the correlation found with effectiveness outcomes. Moreover, charisma and intellectual stimulation presented the higher correlations with satisfaction. Hobman et al. (2011) reported that intellectual stimulation of the leader had a significant positive relationship with satisfaction and performance mediated by members' identification with the leader. Additionally, transformational leadership as a whole and its sub-dimension has been related to affective commitment (Rafferty \& Griffin, 2004; Stinglhamber et al., 2015). In a study conducted by Rafferty and Griffin (2004), although they initially hypothesized a relationship between vision and affective commitment, results showed that only intellectual stimulation and inspirational communication were statistically related to this outcome. Although this study was conducted at the individual level, it highlights the complex and multifactorial antecedents for the development of team affectivity and its link to leadership behaviors (Collins et al., 2013).

Although research related to the influence of each transformational leadership sub-dimension on team learning is scarcer, it is well documented how leaders help to create a team environment in which members openly engage in learning processes and activities (Edmondson, 1999). 
Leaders who articulate a vision and inspire followers, attend followers needs and concerns, and behave in admirable ways provide a context with greater cohesion, trust, and coordination (García-Guiu, Moya, Molero, \& Moriano, 2016; Zhang, Cao, \& Tjosvold, 2011) which undoubtedly leads to team learning. Towler, Arman, Quesnell, and Hoffman (2014), from a training perspective, found that trainers who demonstrated behaviors such as intellectual stimulation, visionary content, and individual attention influenced positive affect, which translates in skill acquisition and transfer of knowledge. In sum, and bearing on team literature, there are number of affective and non-affective factors (i.e., task, coordination, cohesion, group size, interactions between group members) that influence team processes (Collins et al., 2013; Kozlowski \& Bell, 2003; Kozlowski \& Ilgen, 2006); transformational leadership (i.e., intellectual stimulation in particular) and positive affect, are just one of these possible explanations.

\section{Practical Implications}

Bearing on the result of the present study, organizations should invest in developing leaders that are capable of intellectually stimulating their teams. This has implications to both team effectiveness (in terms of team learning), and team well-being (in terms of positive affect). As stated by Hannah and Lester (2009) "leaders are social architects and orchestrators of emergent process relevant to learning" (p. 35). Organizational management should consider leadership developing programs that include a specific component related to how leaders can stimulate learning behaviors in their teammates and how to regulate and create the positive emotional context of the team.

For example, leadership development programs should incorporate practical session not only focused on transformational leadership as a whole but also including specific exercises where leaders can develop their skills to intellectually challenge their team. This may include role modeling exercises on how to challenge their team members to see problems in new ways, being open to experimentation, and to infuse positive criticism inside their teams.

Leaders can be trained as learning coaches to focus on the development of their team, minimizing suboptimal contributions of its members, and fostering advancement of knowledge, skills, idea generation, and reflexivity for performance improvement. Previous research indicates that leader empowerment behavior (which includes leaders' actions that emphasize followers' development, coaching, monitoring, and feedback) facilitates effective performance outcomes through team learning (Burke et al., 2006). Thus, organizational management should consider investing resources to promote leaders' skills and contextual factors that stimulate team members to openly express ideas and suggestions, as well as to collaboratively evaluate each other's ideas and assumptions. Moreover, leaders have to be aware on the impact they have in their team positive affect climate and how this climate may contribute to build enduring cognitive and social resources. Affectivity must be considered in organizations not just as a well-being indicator, but also as an initiator of positive outcomes such as learning.

\section{Limitation and future studies}

This study contributes to the understating of the role leadership intellectual stimulation and team positive affect to team learning. Even though this study used a large and heterogeneous sample, the results of this study have some limitations that should be addressed in future studies. First, all variables were collected from self-reported measures at the same time, although results from confirmatory factor analysis test suggested discriminant validity of scales. Future studies should include data collected from other informants (i.e., supervisors) or provide temporal lags between measures.

Additionally, this study does not consider the type of team (e.g., self-managed, multidisciplinary) as other studies have done 
(e.g., Edmondson, 1999; Van der Vegt \& Bunderson, 2005). This could compromise the generalizability of the results. However, results suggest that, for diverse teams from different organizations, intellectual stimulation of the leader is important for both team learning and team positive affect.

Finally, this was a cross-sectional study, thus it is not possible to reach decisive conclusions about the causation between variables in the model. Future longitudinal designs should be conducted to examine a possible causal relationship between intellectual stimulation and team positive affect. This would also contribute to test the existence of gain spirals of team positive affect, their relationship with other social resources, and their effect on team learning over time.

\section{Conclusion}

This study provides evidence of the strong influence that leadership intellectual stimulation have on team learning and team positive affect, as well as the potential of positive affect to stimulate team learning. Positive affect serves as a partial mediator between leadership intellectual stimulation and team learning, contributing to explain significant additional variance. In an economy and organizational context that requires constant changes, leaders that encourage continuous learning within their team contribute to both the way the team learns and the way the team feels. This suggests the importance of developing leaders' behaviors that encourage learning and team positive affect contexts which contributes to team learning and hence to performance.

\section{Acknowledgements}

This research was supported by a grant from the Spanish Ministry of Economy and Competitiveness (\#PSI2011-22400) and Generalitat Valenciana (Santiago Grisolía Scholarship Program).

\section{References}

Bass, B. M. (1985). Leadership and performance beyond expectations. New York: The Free Press.

Becker, T. E., Atinc, G., Breaugh, J. A., Carlson, K. D., Edwards, J. R., \& Spector, P. E. (2016). Statistical control in correlational studies: 10 essential recommendations for organizational researchers. Journal Organizational Behavior, 37(2), 157-167. ht tps://doi.org/10.1002/job.2053

Bentler, P. M. (1990). Comparative fit indexes in structural models. Psychological Bulletin, 107(2), 238-246. https:// doi.org/10.1037/0033-2909.107.2.238

Biemann, T., Cole, M. S., \& Voelpel, S. (2012). Within-group agreement: On the use (and misuse) of rwg and $\operatorname{rwg}(\mathrm{j})$ in leadership research and some best practice guidelines. The Leadership Quarterly, 23(1), 66-80. https:// doi.org/10.1016/j.leaqua.2011.11.006

Bliese, P. D. (2000). Within-group agreement, non-independence, and reliability: Implications for data aggregation and analysis. In K. J. Klein, \& S. W. J. Kozlowski (Eds.), Multilevel Theory, Research, and Methods in Organizations (pp. 349-381). San Francisco, CA: Jossey-Bass.

Bono J. E., Foldes H. J., Vinson G., \& Muros J. P. (2007). Workplace emotions: The role of supervision and leadership. Journal of Applied Psychology, 92(5), 1357-1367. https ://doi.org/10.1037/0021-9010.92.5.1357

Burke, C. S., Stagl, K. C., Klein, C., Goodwin, G. F., Salas, E., \& Halpin, S. M. (2006). What type of leadership behaviors are functional in teams? A meta-analysis. The Leadership Quarterly, 17(3), 288-307. https://doi.org/1 0.1016/j.leaqua.2006.02.007

Carmeli, A., \& Sheaffer, Z. (2008). How learning leadership and organizational learning from failures enhance perceived organizational capacity to adapt to the task environment. The Journal of Applied Behavioral Science, 44(4), 468-489. https://doi.org/10.1177/00 21886308323822 
Chan, D. (1998). Functional relations among constructs in the same content domain at different levels of analysis: A typology of composition models. Journal of Applied Psychology, 83(2), 234-246.

Chi, N. W., Chung, Y. Y., \& Tsai, W. C. (2011). How do happy leaders enhance team success? The mediating roles of transformational leadership, group affective tone and team processes. Journal of Applied Social Psychology, 41 (6), 1421-1454. https:// doi.org/10.1111/j.1559-1816.2011.00767.x

Chi, N. W., \& Huang, J. C. (2014). Mechanisms linking transformational leadership and team performance: The mediating roles of team goal orientation and group affective tone. Group and Organizational Management, 39(3), 300-325. https://doi.or $\mathrm{g} / 10.1177 / 1059601114522321$

Collins, A. L., Lawrence, S. A., Troth, A. C., \& Jordan, P. J. (2013). Group affective tone: A review and future research directions. Journal of Organizational Behavior, 34(S1), S43-S62. https://doi.org/10.1002/job.1887

Cruz-Ortiz, V., Salanova, M., \& Martínez, I. M. (2013a). Liderazgo transformacional y desempeño grupal: Unidos por el engagement grupal. Revista de Psicología Social, 28(2), 1-14.

Cruz-Ortiz, V., Salanova, M., \& Martínez, I. M. (2013b). Liderazgo transformacional: Investigación actual y retos futuros. Universidad Ë Empresa, 25, 13-32.

Dumdum, U. R., Lowe, K. B., \& Avolio, B. J. (2002). A meta-analysis of transformational and transactional leadership correlates of effectiveness and satisfaction: An update and extension. In B. J. Avolio, \& F. J. Yammarino (Eds.), Transformational and charismatic leadership: The road ahead (pp. 35-66). Oxford: Elsevier Science.

Edmondson, A. C. (1999). Psychological safety and learning behavior in work teams. Administrative Sceince Quarterly, 44, 350-383. https://doi.org/10.2307/2666999

Edmondson, A. C. (2002). The local and variegated nature of learning in organizations: A group level-perspective. Organization Science, 13(2), 128-146. https: //doi.org/10.1287/orsc.13.2.128.530

Edmondson, A. C. (2003). Speaking up in the operating room: How team leaders promote learning in interdisciplinary action teams. Journal of Management Studies, 40 (6), 1419-1452. https://doi.org/10.1111/1467-6 486.00386

Edmondson, A. C., Dillon, J. R., \& Roloff, K. (2007). Three perspectives on team learning: Outcome improvement, task mastery, and group process. In J. P. Walsh, \& A. P. Brief (Eds.), Academy of Management Annals (pp. 269-314). New York: Psychology Press.

Fredrickson, B. L. (2001). The role of positive emotions in positive psychology: The broaden-and-build theory of positive emotions. American Psychologist, 56(3), 218-226. https://doi.org/10.1037/0003-066 X.56.3.218

Fredrickson, B. L. (2003). Positive emotions and upward spirals in organizational settings. In K. S. Cameron, J. E. Dutton, \& R. E. Quinn (Eds.), Positive Organizational Scholarship (pp. 163-175). San Francisco, CA: BerrettKoehler Publishers.

García-Guiu, C., Moya, M., Molero, F., \& Moriano, J. A. (2016). Transformational leadership and group potency in small military units: The mediating role of group identification and cohesion. Journal of Work and Organizational Psychology, 32(3), 145-152.

Gilmore, P. L., Hu, X., Wei, F., Tetrick, L. E. $\&$ Zaccaro, S. J. (2012). Positive affectivity neutralizes transformational leadership's influence on creative performance and organizational citizenship behaviors. Journal Organizational Behavior, 34(8), 1061-1075. https://doi.org/10.1002/job.183 3

Hannah, A. T., \& Lester, P. B. (2009). A multilevel approach to building and leading learning organizations. The Leadership Quarterly, 20, 34-48. 
Israel Sánchez-Cardona, Marisa Salanova Soria, Susana Llorens-Gumbau.

Hernández-Baeza, A., Araya Lao, C., García Meneses, J., \& González Romá, V. (2009). Leader charisma and affective team climate: The moderating role of the leader's influence and interaction. Psicothema, 21(4), 515-520.

Hetland, H., Skogstad, A., Hetland, J., \& Middelsen, A. (2011). Leadership and learning climate in a work setting. European Psychologist, 16(3), 163-173. https://doi.org /10.1027/1016-9040/a000037

Hobman, E. V., Jackson, C. J., Jimmieson, N. L., \& Martin, R. (2011). The effects of transformational leadership behaviour on followers outcomes: An identity-based analysis. European Journal of Work and Organizational Psychology, 20(4), 553-580.

Hu, L. T., \& Bentler, P. (1999). Cutoff criteria for fit indexes in covariance structure analysis: Coventional criteria versus new alternatives. Structural Equation Modeling, 6(1), 1-55. https://doi.org/10.1080/107055 19909540118

James, L. R. (1982). Aggregation bias in estimates of perceptual agreement. Journal of Applied Psychology, 69(1), 85-98. https:// doi.org/10.1037/0021-9010.69.1.85

James, R. L., Lawrence, R., Demaree, R. G., \& Wolf, G. (1993). $\mathrm{r}_{\mathrm{wg}}$ : An assessment of within-group interrater agreement. Journal of Applied Psychology, 78(2), 306-309.

Judge, T. A., \& Piccolo, R. F. (2004). Transformational and transactional leadership: A meta-Analytic test of their relative validity. Journal of Applied Psychology, 89(5), 755-768. https://doi.org/ 10.1037/0021-9010.89.5.755

Kelly, J., \& Barsade, S. (2001). Mood and emotions in small groups and work teams. Organizational Behavior and Human Decision Processes, 86(1), 99-130. https://doi.org/10. 1006/obhd.2001.2974

Kozlowski, S. W. J., \& Bell, B. S. (2003). Work groups and teams in organizations. In W. C. Borman, D. R. Ilgen, \& R. J. Klimoski (Eds.), Handbook of psychology: Industrial and Organizational Psychology (Vol. 12, pp. 333-375). New York: Wiley-Blackwell.
Kozlowski, S. W. J., \& Ilgen, D. R. (2006). Enhancing the effectiveness of work groups and teams. Psychological Science in the Public Interest, 7(3), 77-124. https://doi.org/10.11 11/j.1529-1006.2006.00030.x

Lebreton, J. M., \& Senter, J. L. (2008). Answers to 20 questions about interrater reliability and interrater agreement. Organizational Research Methods, 11(4), 815-852. https://d oi.org/10.1177/1094428106296642

Morgeson, F. P., DeRue, D. S., \& Karam, E. P. (2010). Leadership in team: A functional approach to understanding leadership structure and processes. Journal of Management, 36(1), 5-39. https://doi.org $/ 10.1177 / 0149206309347376$

Nielsen, K., \& Munir, F. (2009). How do transformational leadership influence followers' affective well-being? Exploring the mediating role of self-efficacy. Work $\mathcal{G}$ Stress, 23(4), 313-329. https:// doi.org/10.1080/02678370903385106

Pirola-Merlo, A., Hartel, C. E. J., Mann, L., \& Hirst, G. (2002). How leaders influence the impact of affective events on team climate and performance in $R \& D$ teams. The Leadership Quarterly, 13(5), 561-581. https: //doi.org/10.1016/S1048-9843(02)00144-3

Podsakoff, P. M., MacKenzie, S. B., Lee, J., \& Podsakoff, N. P. (2003). Common method biases in behavioral research: A critical review of the literature and recommended remedies. Journal of Applied Psychology, 88(5), 879-903. https://doi.org/10.1037/00 21-9010.88.5.879

Preacher, K. J., \& Hayes, A. F. (2008). Asymptotic and resampling strategies for assessing and comparing indirect effects in multiple mediator models. Behavior Research Methods, 40(3), 879-891.

Rafferty, A. E., \& Griffin, M. A. (2004). Dimensions of transformational leadership: Conceptual and empirical extensions. The Leadership Quarterly, 15(3), 329-354. https: //doi.org/10.1016/j.leaqua.2004.02.009

Salanova, M., Llorens, S., Cifre, E., \& Martínez, I. M. (2012). We need a Hero! Toward a validation of the Healthy and 
Resilient Organization (HERO) Model. Group Eु Organization Management, 37(6), 785-822. https://doi.org/10.1177/10596011 12470405

Salanova, M., Llorens, S., \& Schaufeli, W. B. (2011). Yes, I Can, I feel good, and I just do it!: On gain cycles and spirals of efficacy beliefs, affect and engagement. Applied Psychology: An International Review, $60(2), 255-285$. https://doi.org/10.1111/j.1 464-0597.2010.00435.x

Sarin, S., \& McDermott, C. (2003). The effect of team leader characteristics on learning, knowledge application, and performance of cross-functional new product development teams. Decision Sciences, 34(4), 707-739. https://doi.org/10. $1111 / \mathrm{j} .1540-5414.2003 .02350 . \mathrm{x}$

Scherer, K. R., \& Tran, V. (2001). Effects of emotion on the process of organizational learning. In A. Berthoin Antal, J. Child, M. Dierkes, \& I. Nonaka (Eds.), Handbook of Organizational Learning and Knowledge (pp. 369-392). New York: Oxford University Press.

Sekerka, L. E., \& Fredrickson, B. L. (2008). Establishing positive emotional climates to advance organizational transformation. In N. A. Ashkanasy, \& C. L. Cooper (Eds). Research Companion to Emotion in Organizations (pp. 531-545), Northampton, MA: Edward Elgar Publishing.

Song, J. H., Kolb, J. A., Lee, U. H., \& Kim, H. K. (2012). Role of transformational leadership in effective organizational knowledge creation practices: Mediating role effect of employees' work engagement. Human Resources Development Quarterly, 23(1), 65-101. https://doi.org/10.1002/hrdq.2112 0

Stinglhamber, F., Marique, G., Caesens, G., Hanin, D., \& De Zanet, F. (2015). The influence of transformational leadership on followers' affective commitment: The role of perceived organizational support and supervisor's organizational embodiment. Career Development International, 20(6),
583-603. https://doi.org/10.1108/CDI-12-2 014-0158

To, M. L., Tse, H. H. M., \& Ashkanasy, N. M. (2015). A multilevel model of transformational leadership, affect, and creative process behavior in work teams. The Leadership Quarterly, 26(4), 543-556. https://doi.org/10.1016/j.leaqua.2 015.05 .005

Towler, A., Arman, G., Quesnell, T., \& Hoffman, L. (2014). How Charismatic trainers inspire others to learn through positive affectivity. Computers in Human Behavior, 32, 221-228. https://doi.org/10.1016/j.chb.2013.12.002

Tsai, W. C., Chen, H. W., \& Cheng, J. W. (2009). Employee positive moods as a mediation linking transformational leadership and employee work outcomes. The International Journal of Human Resources Management, 20(2), 206-219. https://doi.org/10.1080/09 58519080252871

Vacharkulksemsuk, T., \& Fredrickson, B. L. (2013). Looking back and glimpsing forward: The broaden-and-build theory of positive emotions as applied to organizations. In A. B. Bakker (Ed.), Advances in Positive Organizational Psychology (Vol. 1, pp. 45-60). Warrington: Emerald.

Van den Bossche, P., Gijselaers, W. H., Segers, M., \& Kirschner, P. A. (2006). Social and cognitive factors driving teamwork in collaborative learning environments: Team learning beliefs and behaviors. Small Group Research, 37(5), 490-521. https://doi.org/10 $.1177 / 1046496406292938$

Van der Vegt, G. S., \& Bunderson, J. S. (2005). Learning and performance in multidisciplinary teams: The importance of collective team identification. Academy of Management Journal, 48(3), 532-547. https: //doi.org/10.5465/AMJ.2005.17407918

Vince, R. (2002). The impact of emotion on organizational learning. Human Resources Development International, 5(1), 73-85. http s://doi.org/10.1080/13678860110016904 
Warr, P. (1990). The measurement of well-being and other aspects of mental health. Journal of Occupational Psychology, 63(3), 193-210.

Zhang, X., Cao, Q., \& Tjosvold, D. (2011). Linking Transformational Leadership and Team Performance: A Conflict Management Approach. Journal of Management Studies, 48(7), 1586-1611. https://doi.org/10.1111/j.14676486.2010.00974.x

Zhou, Q., Hirst, G., \& Shipton, H. (2012). Context matters: Combined influence of participation and intellectual stimulation on the promotion focusemployee creativity relationship. Journal of Organizational Behavior, 33(2), 894-909. ht tps://doi.org/10.1002/job.779

\section{Notes}

* Research article. 